\title{
Purchase Intention in the Fashion Industry on Local and International E-Commerce in Indonesia
}

\author{
Lim Sanny, Management Department, Bina Nusantara University, Jakarta, Indonesia \\ iD https://orcid.org/0000-0002-9100-719X
}

Tita Dwi Julianto, Bina Nusantara University, Jakarta, Indonesia

Serafim Savionus, Bina Nusantara University, Jakarta, Indonesia

Beni Widarman bin Yus Kelena, Azman Hashim International Business School, Universiti Teknologi, Malaysia

\begin{abstract}
The purpose of this research is to examine the impact of the two categories of sales promotional tools (monetary and non-monetary) on purchase intention with the consideration of consumers' perceived quality for fashion products in local and international e-commerce. As the competition between local and international e-commerce is increasingly fierce, it requires an appropriate sales promotion strategy that is in accordance with customer perceptions in Indonesia to capture customer purchase intention. This research is purely quantitative by using primary data through distributing online questionnaires to customers who have shopped fashion products in local or international e-commerce. Path analysis was used to verify the conceptual model and hypotheses in this research. This research confirms that sales promotions (both monetary and non-monetary) affect customers' perceived quality of a product in e-commerce.
\end{abstract}

\section{KEYWORDS}

E-Commerce, Fashion Industry, Path Analysis, Perceived Quality, Purchase Intention, Sales Promotions

\section{INTRODUCTION}

Total internet users in Indonesia for the year 2018 accounts for 171,17 million people out of Indonesia's total population 264,16 million people in 2018 . This has seen a $10,12 \%$ increase compared to the previous year's total internet users of 143,26 million users (APJII, 2019). Google-Temasek and Bain \& Company stated that Indonesia has the largest digital economy value in the ASEAN region and grows the most rapidly. In 2015, Indonesia's digital economy value was US\$ 8 billion, but predicted to reach US\$ 40 billion in 2019 and US\$ 133 billion in 2025. Amongst Southeast Asia countries, Indonesia is "the largest and fastest growing Internet economy in the region" (Google \& Temasek/ Bain, 2019) well on track preceding Vietnam, Philippines, Thailand, Malaysia, and Singapore.

Over the last years, to reach out new markets and escalate more sales businesses have shifted from the traditional brick-and-mortar sales to the usage of online e-commerce platforms. E-commerce can be defined as "the electronic process by which individuals or organizations make a transaction, such as buy, sell, transfer, or exchange products, services and/or information" as explained before by Turban, McLean, and Weatherbe (2004) in Alyoubi (2015). E-commerce also refers to the aspects of online

DOI: 10.4018/IJABIM.20220701.oa4

This article published as an Open Access article distributed under the terms of the Creative Commons Attribution License (http://creativecommons.org/licenses/by/4.0/) which permits unrestricted use, distribution, and production in any medium, provided the author of the original work and original publication source are properly credited. 
business involving exchanges between customers, business partners and vendors (Joseph, 2019:15). Therefore, e-commerce is a place where everyone can start a business and do business transactions, including Customer to Customer (C2C), Customer to Business (C2B), Business to Customer (B2C), and Business to Business (B2B).

There are multiple choices of e-commerce sites in Indonesia with many different deals and features. Shopee, Lazada, Tokopedia, and Bukalapak are some of the popular e-commerce sites or applications. As we can see in the graph above, Shopee and Lazada were the top 2 most visited e-commerce websites in Southeast Asia for 2019, with Tokopedia and Bukalapak following behind in top 3 and 4. Noting that Shopee and Lazada have established their presence in 6-7 countries such as Indonesia, Singapore, Malaysia, Thailand, Vietnam, Philippines, and Taiwan. While Tokopedia and Bukalapak only operate in Indonesia, surely they are showing potential that they are able to compete with foreign e-commerce.

As in Indonesia itself, the origin country of Tokopedia and Bukalapak, from mid to the end of 2019 (Q3-Q4) Shopee had overcome other e-commerce platforms (including Tokopedia and Bukalapak) and became the number one top e-commerce with the most monthly active users. By the end of 2019 (Q4) Lazada also overcame Bukalapak with their monthly active users and became top 3 . In the end of 2019, most of the customers in Indonesia started to shift their preference towards foreign e-commerce platforms. Looking at this situation, soon Indonesia's market will be monopolized by foreign e-commerce platforms. One of the key differences in local and foreign e-commerce is in international e-commerce, they provide multinational transactions (as they operate in more than 1 countries) for their customers. This feature provides their customers with more choices, like more variant, quality choices, and even prices of the product. To prevent foreign e-commerce from dominating Indonesia's market, our local e-commerce immediately needs to revamp their strategies to be more suitable with customers' perception in Indonesia, so they're able to capture customers' purchase intention and increase their sales.

Statista reported the total revenue of the e-commerce sector in Indonesia amounts to US\$18.764 million in 2019, with the fashion industry as the market's largest segment with a volume of US\$4.792 million in 2019, an increase of 54\% compared to 2018. Fashion seems to be playing the biggest role in the market. Badan Ekonomi Kreatif Indonesia in the OPUS 2019 creative-economy outlook presented a survey conducted by Snapcart in the year 2018 had shown the Fashion \& Accessories industry as the category with the most purchases made in e-commerce, $48.2 \%$ in amount. The fashion industry is promising in Indonesia and is expected to reach a revenue showing an annual growth rate (CAGR $2020-2024$ ) of $16.8 \%$, resulting in a market volume of US $\$ 12.592$ million by 2024 , according to Statista. Also, Statista forecasted that $35 \%$ of total market revenue will be generated through online sales by 2024 . As a developing country rich in raw materials with large easily influenced potential markets, the fashion industry keeps on taking its place in the aforementioned country. As a promising business sector, there are many business players in this industry. Considering the many options, consumers have the free will to make comparisons in evaluating the best options.

In Taiwan, monetary promotions activities exhibit a stronger influence on purchase intentions than that from non-monetary promotions (Pai, Chen, Yeh, \& Metghalchi, 2017). Santini et al. (2015) also proved monetary promotions to have a greater influence on purchase intention. But cited from Aigner, Wilsen, \& Geisendorf (2019), previous studies conducted by Chandran \& Morwitz (2006) and Diamond \& Sanyal (1990) conclude the use of non-monetary promotions are also considered effective as they increase consumers' purchase intentions.

There is still little attention given to study non-monetary promotions (Liao, 2006; Carpenter \& Moore, 2008; Boschetti, 2017). There are studies that have analyzed the role of monetary and nonmonetary sales promotions on perceived quality for instance Salelaw \& Singh (2016) found that monetary promotions positively affect perceived quality and non-monetary promotions negatively affect perceived quality. Nikabadi, Safui, \& Agheshlouei (2015) found monetary promotions' influence positive toward the building of perceived quality and show a lack of positive and meaningful influence 
by non-monetary promotions. Shen (2019) found that both monetary and non-monetary promotions have positive influences toward perceived quality, although non-monetary promotions' were stronger. Aside from these, no researchers have studied the impact of sales promotions (monetary promotions and non-monetary promotions) on purchase intentions through the mediation of perceived quality, neither in the e-commerce sector nor in Indonesia.

Hence to fill this gap, in this research authors aim to investigate the impact of sales promotions (monetary promotions and non-monetary promotions) on Indonesia's customer purchase intentions through the mediation of perceived quality and give insights for Indonesian e-commerce on how to develop and improve an appropriate sales promotion strategy.

\section{BACKGROUND}

The global fashion industry has reached new heights over the past years. In Indonesia, the fashion category in e-commerce accounts for around US\$4.792 billion of revenue in 2019, making it the largest contributor in Indonesia's e-commerce sector (Statista, 2019). Such substantial amount has been driven by strong demand for fashion products along with the growth of the country's emerging market.

Monetary promotions are a strategy that deducts the original selling price of a product or service, such as giving price discounts or reductions, providing a money saving benefit to consumers (Sinha \& Verma, 2020). These include coupons, rebates, and discounts (Chandon et al. in Santini et al., 2015). Monetary promotions are used to obtain short-term financial incentives (Yoo, Donthu, \& Lee in Salelaw \& Singh, 2016). Non-monetary promotions are promotions that offer a non-monetary stimulus that attract customers' attention because of their additional benefit that they provide, beyond the product itself (Cruz-Cunha, Moreira, \& Varajão, 2014:350) such as gifts, bonus, chances of winning contests, and sweepstakes upon purchasing a product (Sinha \& Verma, 2020). Non-monetary promotions are more favorable for the long run (Yi \& Yoo, 2011; Sinha \& Verma, 2020). Although the benefits of non-monetary promotions are not always related to short-term increased sales (Nbudisi \& Moi in Santini et al., 2015), these promotions are related to a long term effects between buyers and sellers, such as strengthening their relationships (Kwok \& Uncles in Santini et al., 2015).

Perceived quality can be defined as "the consumer's subjective judgment about a product's overall excellence or superiority" (Zeithaml in Salelaw \& Singh, 2016). In other words, perceived quality is how a product's performance is perceived in the eyes of customers compared to the expectation of the product's performance itself. Saleem et al. (2015) stated that customers considered perceived quality as a more specific concept based on product and service features. Before purchasing a product, customers have some perceptions and/or expectations about the quality of the product, and often compare it with the price. Therefore, perceived quality is seen as the main driver of purchase intention (Jacoby \& Olson, 1985; Asshidin, Abidin, \& Borhan, 2016). This view is supported by Jones et al. (2002) in Lee, Goh, \& Noor (2019), who argued that perceived quality has a positive correlation to purchase intention.

Purchase Intention is a situation where a consumer tends to buy a certain product in certain conditions. (Morinez et al., 2007; Mirabi, Akbariyeh, \& Tahmasebifard, 2015) and are "frequently used to forecast sales of existing products and services" as well as sales potential for new products (Asshidin, Abidin, \& Borhan, 2016). Purchase intention is often used as a tool to predict consumers' buying decisions. Usually, purchase intention is related with perceptions, behavior, and interest of consumers. In the changing process from purchase intention to purchase decisions, there's some possibility that these intentions do not turn into purchase decisions. Consumers can change their purchase intention because of the influence from the price, quality of the product, and value. Other than that, consumers are also affected by internal or external motivations during the process (Gogoi, 2013; Mirabi, Akbariyeh, \& Tahmasebifard, 2015).

Yoo in Salelaw and Singh (2016) stated that monetary promotion is seen as a chance or opportunity to obtain short term financial incentives. Monetary promotion or so-called price-related promotions 
are very effective to bring short-term benefits, such as increasing market share, encouraging customers to switch between brands, and generating sales traffic (Salelaw \& Singh, 2016). Aside from all the benefits that they present, frequent use of monetary promotions may not be a good option. Many scholars state that frequent use of monetary promotion can confuse customers and lead to an image of unstable quality in consumer's mindset and create the wrong evaluation of the quality of the product (Kim \& Hyun, DelVecchio et al. in Nikabadi, Safui, \& Agheshlouei, 2015); (Salelaw \& Singh, 2016). This confusion can result in a mindset where price is seen as a sign of quality. Therefore when a customer purchases a discounted product, they will think it is discounted because of the poorer quality of the product. On the contrary, considering the economic condition and the price sensitivity of the customers, monetary promotions might be a good option to capture customer's purchase intentions without harming the perceived quality of a product. This relation is supported by Nikabadi, Safui, \& Agheshlouei, (2015) and Salelaw \& Singh (2016) findings in their prior research. Digital marketplaces compete to attract more sales by providing best sales promotion deals. In this study, researchers want to explore the effects of different sales promotional tools to induce purchase intentions by considering the intervention of perceived quality in consumers' minds.

\section{MAIN FOCUS OF THE ARTICLE}

\section{Issues, Controversies, Problems}

Every business player creates various interesting offers to stipulate purchasing intentions from people, to acquire the highest sales. Purchase intention is referred to as consumers' preference to buy the product or service (Younus, Rasheed, \& Zia, 2015) and is deemed accurate for predicting purchase decisions (Pai, Chen, Yeh, \& Metghalchi, 2017). Because of the amount of attractive product deals and offers online, therefore marketplaces must provide the most appealing ones in order to acquire consumers' purchasing intentions.

As Richardson, Dick, and Jain state in Das (2015), perceived quality has a large influence on the consumer decision making process. When evaluating a purchase, consumers often compare the price and quality of a product within each platform selling the product, to know which platform has the best price and deals. They also calculate the barter value which is the price of the product and the quality of the product itself, whether it is worth the purchase or not, or it is better than other distribution places/platforms or not. Especially in online shopping, customers tend to consider whether the certain goods to be purchased would in reality have the good quality in accordance to their expectations or not, or would they attain an authentic product or a fake one. This situation will affect how consumers perceive the product's quality. According to Zeithaml (1988) in Salelaw \& Singh (2016), perceived quality is defined as "the consumer's subjective judgment about a product's overall excellence or superiority". A consumer's perception of quality will be a fundamental to the reasoning behind the intentions to buy. Perceived quality is regarded as the main driver of purchase intention (Jacoby \& Olson, 1985; Asshidin, Abidin, \& Borhan, 2016). Previous researches argue that a brand's success involves its product quality (Erdem et al., 2004; Wulf, 2005; Choi \& Coughlan, 2006; Alenazi, Almotairi, \& Al-Meshal, 2015), and a low perceived quality is regarded as a negative consequence of using promotions (Alenazi, Almotairi, \& Al-Meshal, 2015). That is, when a consumer discerns the promotion and associates it with selling a bad quality product. Seeing the importance of this matter, it is vital to understand the effects of promotion strategies on consumers' perceived quality, so that e-commerce players can draw customers' purchase intentions by using the appropriate strategies. "How the purchase intention is influenced" should be explored to enhance their marketing strategies for the sales goal.

According to Stiawan \& Syah (2017), sales promotions are "all activities that communicate a product or service to the target market so that they act to do things immediately". Sales promotions are intended to induce purchases quicker and larger (Kotler, 1988; Jean \& Yazdanifard, 2015). 
There are two types of sales promotions: monetary and non-monetary. Monetary promotions are a strategy that deducts the original selling price of a product or service, such as giving price discounts or reductions, providing a money saving benefit to consumers (Sinha \& Verma, 2020), whereas non-monetary promotions are promotions that offer a non-monetary stimulus that attract customers' attention because of their additional benefit that they provide, beyond the product itself (Cruz-Cunha, Moreira, \& Varajão, 2014:350) such as gifts, bonus, chances of winning contests, and sweepstakes upon purchasing a product (Sinha \& Verma, 2020). Yoo, Donthu, \& Lee (2000) in Salelaw \& Singh (2016) stated that monetary promotions are used to obtain short-term financial incentives, whereas the use of non-monetary promotions is more favorable for the long-run (Yi \& Yoo, 2011; Sinha \& Verma, 2020). Both of the sales promotion tools have beneficial effects, although it is important to note and adjust according to the type and perspective of the customers. For example for price sensitive customers, monetary promotions will be more favorable than non-monetary promotions. On the contrary, for customers with less price sensitivity, monetary promotions may damage the perceived quality of the product.

Considering Indonesia's economic state still put under the category of a lower middle-income country with diverse poverty rates (UNDP) and the national's Ministry of Finance announced declining economy expected to hit the country will reduce to less than 5\% growth in 2020 (KBR) due to the global economic slowdown, people will have the tendency to value money more than product quality. This is true for Saif, Ahmed, Shareef, \& Khalid (2018) who concluded Pakistan consumers are price sensitive and they don't consider price cuts as signal of poor quality, and that lower prices are the main priority of the customers in choosing a product (Nikabadi, Safui, \& Agheshlouei, 2015). Consistent with the previous editions Deloitte Consumer Insights (2017) observed "Indonesian consumers are generally price-sensitive", hence the use of monetary promotions will be suitable without harming the perceived quality of a product. It is because for price-sensitive people, saving money is more valuable and offering price reductions can be considered as an act of valuing customers (Saif, Ahmed, Shareef, \& Khalid, 2018), H1: Monetary Promotions have positive significant influence on Perceived Quality.

Non-monetary promotions such as premiums, free samples, draws, bundles, and contests are seen as a non-price promotion (Palazon \& Ballester, 2005; Mendez, 2015). By using non-monetary promotions, it will not directly cut off the price of a product, instead they choose to add a bonus or value to the targeted product. This action generates a value of "excitement" in customers' minds, and bears countable economic savings (Tong \& Hawley, 2009; Salelaw \& Singh, 2016). Since it is seen as a welfare and joy for customers (Chandon et al. in Nikabadi, Safui, \& Agheshlouei, 2015), non-monetary promotion can strengthen customer's perceived quality. Buil et al. in Zeng \& Hao (2016) indicated that non-monetary promotions positively affect perceived quality. Nikabadi, Safui, \& Agheshlouei (2015) also argued that non-monetary promotion can lead to joyful experiences, as well as arousing positive feelings regarding the products. H2: Non-Monetary Promotions have positive significant influence on Perceived Quality

Monetary promotions are believed to have a strong impact on purchase intentions (Santini et al., 2015). Monetary promotions are valued more and generate higher buying intentions (Alnazer, 2019). Some researchers studied the impact monetary promotions have on purchase intention and found them influential (Santini et al., 2015); (Pai, Chen, Yeh, \& Metghalchi, 2017). Monetary promotions attract consumers by offering price savings opportunities. They have been widely used and proven to stimulate profits (Hendel \& Nevo, 2006; Jean \& Yazdanifard, 2015). The use of monetary promotions such as price discount focus on price, which lead customers to use quantitative reasoning because monetary promotions represent a reduction in loss (Alnazer, 2019) that is, the amount of price a consumer has to pay. Especially in Indonesia for price-sensitive customers, monetary promotions will be more favorable than non-monetary promotions, due to the common ground that saving money to get the item is more valuable because of the instant reward of reduction in the amount they have to pay. Given that competition between e-commerce markets are tightening throughout this pandemic year of the coronavirus, people will tend to cut off spending and e-commerce markets will have to 
optimize their strategies. Though the pandemic hits the world economy hard, still The Economic Report on Indonesia noted there is a rapid development of the digital economy particularly through e-commerce, though it creates greater opportunities for market efficiency, at the same time it tightens competition. Hence, for e-commerce players to capture intentions, monetary promotions would be attractive in the eyes of price-sensitive customers in Indonesia since a slight difference in price matters. H3: Monetary Promotions have positive significant influence on Purchase Intention

Non-monetary promotions are considered as gains (Alnazer, 2019) and because it is seen as an increase of gains, it thus enhances consumers' purchase intentions (Aigner, Wilken, \& Geisendorf, 2019) because consumers do not have to spend more to get an additional value. Non-monetary promotions are non-price related and the value of non-monetary promotions are not directly related to price, so consumers cannot really evaluate the value of the benefit in numbers; instead, they encode it as revenue (Sinha \& Smith, 2000; Shen, 2019). Kim \& Min (2016) in their research about nonmonetary promotions, found that consumers prefer receiving hedonic products as reward rather than utilitarian one in a promotion context. One reason is because hedonic products provide consumers with pleasant feelings and good shopping experience (Shen, 2019). Therefore, in implementing nonmonetary promotion it is important to provide and choose a gift that brings joyful and enjoyable feeling as rewards. According to Sinha \& Verma (2017) non-monetary promotions can enhance consumers' expectations because they don't harm the brand value, and in the end can lead into purchase. In addition, non-monetary promotions are effective in encouraging potential consumers to try out the product for the first time (Cruz-Cunha, Moreira, \& Varajão, 2014:339) and are effective for both hedonic and utilitarian products with more effectiveness for hedonic products (Sinha \& Verma, 2017). In other words, non-monetary promotions strongly attract consumers who seek valueadded benefits and shopping experiences. H4: Non-Monetary Promotions have positive significant influence on Purchase Intention

Perceived quality can be defined as the consumer's judgement about the whole features and characteristics of a product (product overall excellence and superiority) to satisfy customers' needs compared to their expectation (Zeithaml in Das, 2015); (Kotler et al. in Saleem et al., 2015). Mitra and Golder in Das (2015) argued that perceived quality leads to preference and consequently satisfaction, loyalty, sales, and profitability. This concludes that product perceived quality directly influences customers' purchase intention (Saleem et al., 2015). In the purchasing process, customers are always influenced by their preferences and perception of a product, they have some perceptions about the product quality and price before going to purchase the product. When a product has high quality, customers' intention in purchasing it will also be high (purchase with high intensity) (Agbor, Rush \& Oliver in Saleem et al., 2015). Noting the statement of Keller in Das (2015), a consumer may doubt the quality and value of an unfamiliar product or brand due to a lack of information when making a judgement. This is crucial in e-commerce situations, where customers can not see the actual product and may conclude in false judgement of a product. In any case, perceived quality has significant effects on purchase intention. H5: Perceived Quality have positive significant influence on Purchase Intention.

In buyers' perspective, price is seen as a barter value that needs to be sacrificed to get the product or service they want, often equated with money. According to researchers of consumer insight in Indonesia, majority of Indonesian consumers are generally price-sensitive (Deloitte, 2017); (DBS Group Research, 2017); (Snapcart, 2017). Looking at this situation, buyers in Indonesia tend to care more about price rather than quality, as it is confirmed in previous researches about consumers with price sensitivity (Nikabadi, Safui, \& Agheshlouei, 2015); (Salelaw \& Singh, 2016). When purchasing a discounted product (or product with monetary promotion in it), they don't consider price cuts as a signal of poorer quality, instead they see it as an opportunity to get high quality products with cheaper prices (Nikabadi, Safui, \& Agheshlouei, 2015). Hence, sellers use monetary promotions to attract customers' purchase intention by reducing the barter value for the same quality of a product. H6: Monetary Promotions have positive significant influence on Purchase Intention through Perceived Quality. 
Customers consider the perception of quality as a specific concept based on product features (Saleem et al., 2015). A low perceived quality may result in a lower buying intention, as perceived quality is regarded as the main driver of purchase intention (Jacoby \& Olson, 1985; Asshidin, Abidin, \& Borhan, 2016). This view is supported by Jones et al. in Lee, Goh, \& Noor (2019), who argued that perceived quality has a positive correlation to purchase intention. There is no study yet who have analyzed the impact of using non-monetary promotions on generating buying intentions by building perceived quality, and there is little attention given to the study of non-monetary promotions within the literature. Non-monetary promotion is believed to positively affect perceived quality (Buil et al., 2013; Zeng \& Hao, 2016) and perceived quality is believed to be a strong determinant of purchase intention. H7: Non-Monetary Promotions have positive significant influence on Purchase Intention through Perceived Quality.

\section{RESEARCH METHODOLOGY}

Population in this research are consumers in Indonesia who are familiar with e-commerce platforms and have conducted a transaction for fashion products within before. Fashion products were not limited to specific categories. Purposive sampling was used through the use of non-probability sampling. This research utilized enclosed questionnaires. The score weighting to measure questionnaire items utilized Likert scale.

In this research, collected are 266 respondence. 5 persons do not fit criteria 2, as they never shopped in e-commerce and it became 261 persons. 36 persons and 9 persons do not fit criteria 3 , as they never bought fashion products in local or international e-commerce. Therefore, total respondents who fit the sample criteria were 216 respondents. 111 persons chose local e-commerce as their most used platform, and 105 persons chose foreign or international e-commerce as their most used platform. These respondents have come from various backgrounds but have a common ground in which they have purchased fashion items from local or foreign e-commerce. Data analysis for this research using path analysis. The first analysis is done by computing the path between independent variable toward intervening variable, and second by measuring the relation between independent variable toward dependent variable through mediation or intervening variable.

\section{RESULTS AND DISCUSSION}

The majority of respondents were female, amounting to $64.4 \%$ respondents. Compared with the number of male respondents which is only $35.6 \%$. The characteristics of consumers of the fashion industry in e-commerce platforms based on age, the majority are $21-30$ years old by $75.9 \%$. Following behind are the age categories below 20 years old by $15.7 \%, 31$ - 40 years old and $41-50$ years both by $3.2 \%$ and lastly age 51 and above by $1.9 \%$. We can conclude that the majority of users are from $\mathrm{Y}$ and $\mathrm{Z}$ generations, followed by $\mathrm{X}$ generation. It is aligned with Dhanapal (2015) and Salelaw \& Singh (2016) in their research which stated that generation $\mathrm{Z}$ and $\mathrm{Y}$ are more familiar with using internet technology, followed by generation $X$ and lastly by Baby Boomers. As the majority user of the internet technology, the younger generations (generation Z and Y) tend to shop online (Dholakia, Joines et.al in Dhanapal, 2015). Therefore it is aligned with the previous studies, the majority of consumers of the fashion industry in e-commerce platforms are also generation $\mathrm{Y}$ and $\mathrm{Z}$ in this research as they are more connected and aware of the digital world (Salelaw \& Singh, 2016).

Most preferred e-commerce belongs to local e-commerce which amounts to $51.4 \%$ respondents. Trailing behind with a slight difference, is the preference for international or foreign e-commerce by $48.6 \%$. These findings are new insights, as there is a slight difference with Iprice's top used mobile apps for e-commerce in 2019, which are mostly led by foreign or international e-commerce and followed closely by local e-commerce. By looking at this situation, it can be concluded that both local 
and international e-commerces are still fiercely competing with each other, as they keep overtaken one another by a slight difference.

This study seeks the direct and indirect influence, mediated through perceived quality, of monetary and non-monetary promotions on purchase intention in the fashion industry of local and international e-commerce in Indonesia. The results for both local and international e-commerce are shown in 2 substructures of path analysis. The first is the relation between monetary and non-monetary promotions towards perceived quality, the second being the relation between monetary promotions, non-monetary promotions, and perceived quality towards purchase intention.

For the first substructure both of the sales promotions have a positive significant influence on perceived quality in local and international e-commerce, hence hypothesis 1 and 2 are accepted. It can be concluded that by using monetary and non-monetary promotions, it will not damage customers' perceived quality and even can strengthen it. Because the majority of customers (which are college students in this research) see monetary promotions as an opportunity to get fashion products that they need or want with more affordable prices. As for the non-monetary promotions, they see it as a bonus or gift that works as a generous act from the companies that brings joyful experiences and positive feelings towards the products. These results are aligned with the previous studies by Nikabadi, Safui, \& Agheshlouei (2015), Salelaw \& Singh (2016), and Saif, Ahmed, Shareef, \& Khalid (2018).

For the second substructure, interestingly, monetary promotions do not have significant influence toward purchase intention, neither does non-monetary promotions. However, perceived quality has a positive significant influence on purchase intention. These results show that hypothesis $3,4,6,7$ are rejected and hypothesis 5 is accepted. It is proven that customers' in Indonesia use their perceived quality as one of the considerations in purchasing a product. If a product has a high perceived quality, it ensures the product reliability, sustainability, and durability (Saleem et al., 2015). A high perceived quality also indicates high purchase intention (Rush \& Oliver in Das, 2015). Therefore, it is important to maintain customers' perceived quality by providing clear and comprehensive information about the product so that customers can make the right judgement about the product. The influence of monetary and non-monetary promotions on purchase intention show interesting results when tested, which is both insignificant. These results are different from previous studies by Pai, Chen, Yeh, \& Metghalchi (2017) who argued both of monetary and non-monetary promotions have significant influences on purchase intention. We consolidate that monetary promotion specifically discount for fashion products sold in e-commerce weave customers rational aspects and prudence, at the expense of acquiring benefits or gains offered which is the product itself, when customers are initiating a purchase. This is explained by Puri in Santini et al. (2015) where their actions are the result of evaluating costs, not the offered benefits. It is also probable that the discount was not deemed big enough for the gains. Based on the indirect influence we can conclude that customers of the fashion industry in both local and international e-commerce see sales promotion and the product's quality separately in considering a purchase. They are not aware of the possibility of different prices, different quality of the product. This condition may be due to the nature of fashion brands in e-commerce that rarely sells rejected products with cheaper prices online. They prefer selling standardized products to keep their reputation.

The same for the influence of non-monetary promotion on purchase intention, which also insignificant. Most of Indonesian customers tend to focus only on the product that they need or want and the price that they need to sacrifice for it. Although non-monetary promotion gives more value to the products, it is not strong enough to drive purchase intention because a customer may have wanted the sold product but not the specified free gift instead. Therefore, when non-monetary promotions are intermediated by perceived quality, the influence of perceived quality is not strong enough to increase purchase intention. 
Table 1. Structures Results Summary for Local E-Commerce

\begin{tabular}{|c|c|c|c|}
\hline \multicolumn{4}{|l|}{ Direct Influence } \\
\hline & Path Coefficient & Sig & Result \\
\hline $\begin{array}{l}\text { Monetary Promotions -> } \\
\text { Perceived Quality }\end{array}$ & 0.241 & 0.016 & Significant \\
\hline $\begin{array}{l}\text { Non-Monetary Promotions } \\
->\text { Perceived Quality }\end{array}$ & 0.326 & 0.001 & Significant \\
\hline $\begin{array}{l}\text { Monetary Promotions -> } \\
\text { Purchase Intention }\end{array}$ & 0.167 & 0.066 & Insignificant \\
\hline $\begin{array}{l}\text { Non-Monetary Promotions } \\
->\text { Purchase Intention }\end{array}$ & -0.166 & 0.075 & Insignificant \\
\hline $\begin{array}{l}\text { Perceived Quality -> } \\
\text { Purchase Intention }\end{array}$ & 0.622 & 0.000 & Significant \\
\hline \multicolumn{4}{|l|}{ Indirect Influence } \\
\hline $\begin{array}{l}\text { Monetary Promotions -> } \\
\text { Purchase Intention through } \\
\text { Perceived Quality }\end{array}$ & \multicolumn{3}{|l|}{$0.241 \times 0.622=0.150$} \\
\hline $\begin{array}{l}\text { Non-Monetary Promotions } \\
\text {-> Purchase Intention } \\
\text { through Perceived Quality }\end{array}$ & \multicolumn{3}{|l|}{$0.326 \times 0.622=0.203$} \\
\hline
\end{tabular}

Source: Results of Data Processing (2020)

Table 2. Structures Results Summary for International E-Commerce

\begin{tabular}{|c|c|c|c|}
\hline \multicolumn{4}{|l|}{ Direct Influence } \\
\hline & Path Coefficient & Sig & Result \\
\hline $\begin{array}{l}\text { Monetary Promotions -> } \\
\text { Perceived Quality }\end{array}$ & 0.224 & 0.024 & Significant \\
\hline $\begin{array}{l}\text { Non-Monetary Promotions } \\
\text {-> Perceived Quality }\end{array}$ & 0.486 & 0.000 & Significant \\
\hline $\begin{array}{l}\text { Monetary Promotions -> } \\
\text { Purchase Intention }\end{array}$ & 0.162 & 0.147 & Insignificant \\
\hline $\begin{array}{l}\text { Non-Monetary Promotions } \\
\text {-> Purchase Intention }\end{array}$ & -0.161 & 0.185 & Insignificant \\
\hline $\begin{array}{l}\text { Perceived Quality -> } \\
\text { Purchase Intention }\end{array}$ & 0.550 & 0.000 & Significant \\
\hline \multicolumn{4}{|l|}{ Indirect Influence } \\
\hline $\begin{array}{l}\text { Monetary Promotions -> } \\
\text { Purchase Intention through } \\
\text { Perceived Quality }\end{array}$ & \multicolumn{3}{|l|}{$0.224 \times 0.550=0.123$} \\
\hline $\begin{array}{l}\text { Non-Monetary Promotions } \\
\text {-> Purchase Intention } \\
\text { through Perceived Quality }\end{array}$ & \multicolumn{3}{|l|}{$0.486 \times 0.550=0.267$} \\
\hline
\end{tabular}

Source: Results of Data Processing (2020) 


\section{CONCLUSIONS}

Since monetary sales promotion is accepted well without harming the perceived quality of a product, local e-commerce can keep using monetary promotion strategies online. To improve their monetary promotions, e-commerce should collaborate with fashion brands to arrange their promotions strategy by matching it with their customers' cycle and their product life cycle, such as discounts for products in decline state and discounts in the end of the month (after payday). At the same time, e-commerce should research to develop strategies which could build quality perceptions more. Based on the results of this research, non-monetary promotions can build perceived quality for fashion products highly in international e-commerce more than local e-commerce. Looking at this situation, local e-commerce should create and improve their non-monetary promotions by seeking the suitable or preferred type of gift (or other type of non-monetary promotions) for their customers. Because monetary sales promotion does not entice customers to initiate a purchase, local e-commerce platforms along with fashion brands need to work on revamping the discounting strategy, such as utilizing non-frequent but large seasonal discounts such as for payday and mixing with other marketing strategies to reinvigorate customers' interest so that the use of monetary promotions such as discount can finally influence customers to purchase. Due to insufficient influence non-monetary promotions produce toward purchase intention, local e-commerce and fashion brands should research the preferred type of non-monetary promotions. Therefore not only non-monetary promotions can strengthen perceived quality, but also influence customers' purchase intention. Customers' judgement about a whole product is one of the main considerations when purchasing a product especially when it comes to fashion products. Therefore, it is important for local e-commerce to guide their seller to keep the information of a product as clear and complete as possible, so it will not interfere the consideration of purchasing. 


\section{REFERENCES}

Aigner, A., Wilken, R., \& Geisendorf, S. (2019). The Effectiveness of Promotional Cues for Organic Products in the German Retail Market. Sustainability, 11(24), 6986. doi:10.3390/su11246986

Alenazi, S., Almotairi, M., \& Al-Meshal, S. (2015). The Perceived Quality of Store Brands: The Effect of Price Promotion and Quality Guarantees. International Journal of Marketing Studies, 7(4), 88-93. doi:10.5539/ijms. v7n4p88

Alnazer, M. (2019). Consumer Response to Sales Promotion Tools: The Moderating Role of Brand Awareness (Case of Turkish Market). IOSR Journal of Business and Management, 21(1), 18-23.

Alyoubi, A. A. (2015). E-commerce in Developing Countries and How to Develop Them During the Introduction of Modern Systems. Procedia Computer Science, 65, 479-483. doi:10.1016/j.procs.2015.09.127

Asosiasi Penyelenggara Jasa Internet Indonesia. (2019). Penetrasi \& profil perilaku pengguna internet indonesia 2018. APJII.

Asshidin, N. H. N., Abidin, N., \& Borhan, H. B. (2016). Perceived quality and emotional value that influence consumer's purchase intention towards American and local products. Procedia Economics and Finance, 35, 639-643. doi:10.1016/S2212-5671(16)00078-2

Bank Indonesia. (2018). Economic report on Indonesia. Bank Indonesia.

Boschetti, R. I. B., Perin, M. G., de Barcellos, M. D., Sampaio, C. H., \& Basso, K. (2017). Non-monetary sales promotion effects on credit cards. Journal of Financial Services Marketing, 22(1), 3-13. doi:10.1057/s41264017-0017-6

Cruz-Cunha, M. M., Moreira, F., \& Varajão, J. (2014). Handbook of Research on Enterprise 2.0: Technological, Social, and Organizational Dimensions. IGI Global. doi:10.4018/978-1-4666-4373-4

Das, G. (2015). Linkages between self-congruity, brand familiarity, perceived quality and purchase intention: A study of fashion retail brands. Journal of Global Fashion Marketing, 6(3), 180-193. doi:10.1080/2093268 5.2015 .1032316

DBS Group Research. (2017). Industry Focus - Indonesia Consumer. DBSVI.

Deloitte. (2017). Deloitte Consumer Insights - Embracing bricks and clicks in Indonesia. Deloitte Southeast Asia Ltd.

Dhanapal, S., Vashu, D., \& Subramaniam, T. (2015). Perceptions on the challenges of online purchasing: A study from "baby boomers", generation "X" and generation "Y" point of views. Contaduría y Administración, 60(S1), 107-132. doi:10.1016/j.cya.2015.08.003

Google \& Temasek/Bain. (2019). e-Conomy SEA 2019 - Swipe up and to the right: Southeast Asia's $\$ 100$ billion Internet economy. Google \& Temasek/Bain.

iPrice Group, App Annie, \& SimilarWeb. (2019). Year-End Report on Southeast Asia's Map of E-commerce 2019. iPrice.

Jean, W. A., \& Yazdanifard, R. (2015). The Review of how Sales Promotion Change the Consumer's Perception and Their Purchasing Behavior of a Product. Global Journal of Management and Business Research, 15(5-E), $32-37$.

Joseph, P. T. (2019). E-COMMERCE: An Indian Perspective (6th ed.). PHI Learning Private Limited.

Kim, J., \& Min, D. (2016). Designing Customer-Oriented Non-Monetary Promotions in the Tourism Industry. Journal of Travel \& Tourism Marketing, 33(2), 184-196. doi:10.1080/10548408.2015.1044062

Kotler, P., \& Armstrong, G. (2014). Principles of Marketing (15th ed.). Pearson Education Limited.

Lee, J. E., Goh, M. L., \& Noor, M. N. B. M. (2019). Understanding purchase intention of university students towards skin care products. PSU Research Review, 3(3), 161-178. doi:10.1108/PRR-11-2018-0031 
Mendez, M., Bendixen, M., Abratt, R., Yurova, Y., \& O’Leary, B. (2015). Sales Promotion and Brand Loyalty: Some New Insights. International Journal of Education and Social Science, 2(1), 103-117.

Mirabi, V., Akbariyeh, H., \& Tahmasebifard, H. (2015). A Study of Factors Affecting on Customers Purchase Intention. Journal of Multidisciplinary Engineering Science and Technology, 2(1), 267-273.

Nikabadi, M. S., Safui, M. A., \& Agheshlouei, H. (2015). Role of Advertising and Promotion in Brand Equity Creation. Journal of Promotion Management, 21(1), 13-32. doi:10.1080/10496491.2014.946208

Opus. (2019). Creative Economy Outlook. Accessed on 20 December 2019, from www.bekraf.go.id/downloadable/ pdf_file/181161-opus-indonesia.pdf

Pai, F. Y., Chen, C. P., Yeh, T. M., \& Metghalchi, M. (2017). The effects of promotion activities on consumers' purchase intention in chain convenience stores. International Journal of Business Excellence, 12(4), 413. doi:10.1504/IJBEX.2017.085005

Saif, T., Ahmed, M., Shareef, S., \& Khalid, R. (2018). Characteristics of Brand Loyalty: A Study on Apparel Industry. Mediterranean Journal of Basic and Applied Sciences, 2(2), 64-91.

Saleem, A., Ghafar, A., Ibrahim, M., Yousuf, M., \& Ahmed, N. (2015). Product perceived quality and purchase intention with consumer satisfaction. Global Journal of Management and Business Research: E Marketing, 15(1), 21-28.

Salelaw, G. T., \& Singh, A. (2016). The Impact of Sales Promotion on Brand Equity: The Case of Brewery Industry. Journal of Marketing and Consumer Research, 22, 68-81.

Santini, F., Sampaio, C., Perin, M., Espartel, L., \& Ladeira, W. (2015). Moderating Effects of Sales Promotion Types. BAR - Brazilian Administration Review, 12(2), 169-189. doi:10.1590/1807-7692bar2015140057

Sari, D., Pradhana, C., \& Widharto, Y. (2018). Analisis pengaruh advertising dan sales promotion terhadap dimensi brand equity pada produk pelumas mobil fastron. Jurnal SIMETRIS, 9(2), 841-854. doi:10.24176/ simet.v9i2.2412

Shen, Z. (2019). Sales Promotions and Brand Equity: The Moderating Role of Product Type. Advances in Social Science, Education and Humanities Research, 385, 568-572. doi:10.2991/assehr.k.191221.138

Sinha, S. K., \& Verma, P. (2017). Consumer's Response towards Non-Monetary and Monetary Sales Promotion: A Review and Future Research Directions. The Journal of Economic Perspectives, 11, 500-507.

Sinha, S. K., \& Verma, P. (2020). Impact of sales Promotion's benefits on perceived value: Does product category moderate the results? Journal of Retailing and Consumer Services, 52, 101887. doi:10.1016/j. jretconser.2019.101887

Snapcart. (2017). Indonesian Consumer Insights: The Growing Price of Maintaining Customer Loyalty. https:// snapcart.global/indonesian-consumer-insights-customer-loyalty

Stiawan, E., \& Syah, T. Y. R. (2016). Metode Penelitian Manajemen. ALFABETA.

Stiawan, E., \& Syah, T. Y. R. (2017). The Effect of Promotional Benefit on Purchase Intention moderated by the Brain's Tendency of Consumers. Journal of Economics, Business \& Accountancy Ventura, 20(1), 89-95. doi:10.14414/jebav.v20i1.439

UNDP. (2019). About Indonesia. Accessed on 20 December 2019, from https://www.id.undp.org/content/ indonesia/en/home/countryinfo.html

Vo, T. T. N., \& Nguyen, C. T. K. (2015). Factors Influencing Customer Perceived Quality and Purchase Intention toward Private Labels in the Vietnam Market: The Moderating Effects of Store Image. International Journal of Marketing Studies, 7(4), 51-63. doi:10.5539/ijms.v7n4p51

Younus, S., Rasheed, F., \& Zia, A. (2015). Identifying the Factors Affecting Customer Purchase Intention. Global Journal of Management and Business Research, 15(2), 8-14.

Zeng, H., \& Hao, L. (2016). Cross-cultural examination of the effects of promotional framing on consumers' responses: A comparison of China and Pakistan. International Business Review, 25(5), 1020-1029. doi:10.1016/j. ibusrev.2016.01.007 